\title{
Implementasi KTSP Dalam Pembelajaran IPA SMP
}

\author{
Sumiyati \\ Pusat Kurikulum, Balitbang Kemendiknas
}

\begin{abstract}
Abstrak: Penelitian ini bertujuan untuk mengetahui gambaran pelaksanaan yang berkaitan dengan pemberlakuan KTSP khususnya pada pembelajaran IPA di SMP. Jenis penelitian ini adalah penelitian survei dengan jumlah sampel sebanyak 40 orang yang tersebar di 11 SMP Negeri dan Swasta di Kabupaten Bekasi. Data dianalisis dengan menggunakan analisis deskriptif dalam bentuk tabel distribusi frekuensi dan persentase untuk setiap indikator dan untuk setiap dimensi implementasi KTSP. Hasil penelitian ini menunjukkan bahwa: 1) perencanaan program yang terdiri dari pembuatan silabus; pembuatan Rencana Pelaksanaan Pembelajaran (RPP), dan program remedial/pengayaan menunjukkan sebagian besar berada pada kategori cukup, hanya sebagian kecil saja berada pada kategori rendah dan kategori sangat rendah, 2) pelaksanaan program yang terdiri dari implementasi komponen silabus; implementasi komponen RPP, dan program remedial/pengayaan menunjukkan sebagian besar berada pada kategori cukup, dan sebagian kecil berada pada kategori sangat rendah, dan (3) pelaporan program yang terdiri dari penilaian proses dan penilaian hasil menunjukkan sebagian kecil saja berada pada kategori cukup, dan sebagian besar berada pada kategori sangat rendah
\end{abstract}

Kata Kunci: KTSP, IPA di SMP, Kemampuan Guru IPA SMP, Silabus, dan RPP.

\begin{abstract}
This research was aimed at describing teachers opinion about the implementation of the program comprises planning, activities in the classroom, and the report of Science Teaching-Learning of School-Based Curriculum implementation and its factors affecting it. There are 40 respondents from 11 State and Private Junior High Schools in Bekasi District. The instruments consist of questionnaires in the form of Liker Scale. The data is then analyzed using descriptive analyses in tables distributing frequency and percentage for each indicator and each dimension of School-Based Curriculum Implementation. The data shows that (1) The planning of the program: writing syllabus; lesson plan, and remedial/enrichment indicate that most respondents are at moderate level, others are at low level and the others are at very low level. (2) The implementation of the program including syllabus, lesson plan components and remedial/ enrichment indicate most respondents are at moderate level while the remaining are at the very low level., and (3) The report consisting of process and outcome evaluations, indicate that only a few respondents are at moderate level, and most of them are at the level of very low.
\end{abstract}

Key words: school-based curriculum, science at junior high school, Competency of the Science Teachers of Junior High School, syllabus, and lesson plan. 


\section{Pendahuluan}

Berdasarkan informasi dari beberapa pengawas pada beberapa sekolah di Kabupaten Bekasi menunjukkan bahwa implementasi Kurikulum Tingkat Satuan Pendidikan (KTSP) pada SMP Negeri dan Swasta terutama pada pembelajaran IPA belum sepenuhnya diterapkan. Hal ini ditunjukkan bahwa masih ditemukan beberapa guru yang menggunakan strategi pembelajaran lama, guru masih memperlihatkan banyaknya keluhan dan kesulitan yang dialami dalam menerapkan KTSP. Kesulitan tersebut antara lain: 1) guru masih merasa sulit dalam mengindentifikasi karakteristik siswa yang mestinya menjadi pertimbangan dalam mendisain silabus pembelajarannya, 2) guru masih belum terampil dalam menyusun/mengembangan silabus/ persiapan mengajar sesuai dengan tuntutan KTSP,

3) guru masih kesulitan dalam menerapkan metode belajar yang bervariasi di kelas, 4) guru masih mengeluhkan rumitnya sistem evaluasi atau penilaian hasil belajar seperti diharapkan dalam pembelajaran berbasis kompetensi, dan 5) guru masih mengeluhkan sulitnya mengorganisasikan materi secara terpadu dalam pembelajaran IPA.

Beberapa hal di atas menggambarkan bahwa KTSP bukan suatu hal yang mudah untuk diterapkan oleh guru-guru IPA SMP. Pengamatan mengenai hasil pembelajaran di SMP, menunjukkan kurang mampunya peserta didik menghubungkan antara yang dipelajari dan bagaimana pengetahuan itu dimanfaatkan untuk menyelesaikan permasalahan dalam kehidupan sehari-hari. Hal ini dimungkinkan karena peserta didik sebagian hanya memperoleh pengetahuan yang bersifat hafalan dengan tingkat pemahaman yang kurang optimal. Peserta didik hanya tahu bahwa sebagian tugasnya adalah mengenal fakta-fakta namun penyelesaian masalah belum sepenuhnya mereka kuasai. Untuk itu perlu dirancang sebuah kurikulum pembelajaran yang berorientasi pada pencapaian kompetensi

KTSP menuntut kreativitas guru dalam menyusun pembelajaran yang sesuai dengan kondisi lokal, dan pada prinsipnya KTSP bukanlah kurikulum yang baru sama sekali, tetapi merupakan penyempurnaan dari kurikulum berbasis kompetensi yang sudah diujicobakan sebelumnya.Setiap kurikulum yang diberlakukan memiliki ciri-ciri yang bergantung kepada situasi dan kondisi pada saat di mana kurikulum tersebut diberlakukan. KTSP yang direncanakan dapat diberlakukan secara menyeluruh di semua sekolah-sekolah di Indonesia pada tahun 2010 itu juga memiliki beberapa kelebihan jika dibanding dengan kurikulum sebelumnya. Kelebihankelebihan KTSP ini antara lain: 1) mendorong terwujudnya otonomi sekolah dalam penyelenggaraan pendidikan, 2) mendorong para guru, kepala sekolah, dan pihak pengelola manajemen sekolah untuk semakin meningkatkan kreativitasnya dalam penyelenggaraan program-program pendidikan, 3) KTSP sangat memungkinkan bagi setiap sekolah untuk menitikberatkan dan mengembangkan mata pelajaran tertentu sesuai dengan kebutuhan peserta didik, dan 4) KTSP akan mengurangi beban belajar peserta didik yang sangat padat.

Di samping kelebihan, kurikulum yang diberlakukan juga memiliki kelemahannya. Sebagai konsekuansi logis dari penerapan KTSP ini setidak-tidaknya terdapat beberapa kelemahan dalam KTSP maupun penerapannya, diantaranya adalah: 1) kurangnya sumber daya manusia (SDM) yang diharapkan mampu menjusun KTSP pada kebanyakan satuan pendidikan yang ada, 2) kurangnya ketersediaan sarana dan prasarana pendukung sebagai kelengkapan dari pelaksanaan KTSP, 3) masih banyak guru yang belum memahami KTSP secara komprehensif baik konsepnya, penyusunannya maupun prakteknya di lapangan, 4) kurangnya koordinasi antarkomponen penentu kebijakan di daerah dalam melakukan pembinaan kepada satuan pendidikan di wilayahnya, dan 5) penerapan KTSP yang merekomendasikan pengurangan jam pelajaran sulit diterapkan mengingat banyak satuan pendidikan yang merasa kurang waktunya.

Atas dasar uraian di atas, maka rumusan masalahnya adalah "bagaimanakah gambaran implementasi KTSP yang mencakup perencanaan program, pelaksanaan program dan pelaporan hasil pada pembelajaran IPA pada SMP oleh guru mata pelajaran IPA"?

Tujuan Penelitian ini dimaksudkan untuk mengetahui gambaran implementasi KTSP yang mencakup perencanaan program, pelaksanaan program dan pelaporan program pembelajaran 
IPA pada SMP yang dilakukan oleh guru mata pelajaran IPA, melalui pendapat beberapa guru.

\section{Kajian Literatur}

\section{Kurikulum Tingkat Satuan Pendidikan ( KTSP)}

Kurikulum sebagaimana diamanatkan dalam UU No. 20 Tahun 2003 tentang Sistem Pendidikan Nasional adalah seperangkat rencana dan pengaturan mengenai tujuan, isi, dan bahan pelajaran serta cara yang digunakan sebagai pedoman penyelenggaraan kegiatan pembelajaran untuk mencapai tujuan pendidikan tertentu. (UUSPN No.20/2003 : 7) Oleh karena itu, isi kurikulum merupakan komponen yang sangat menentukan keterlaksanaan program pembelajaran yang merupakan strategi dalam mencapai tujuan pendidikan.

Pentingnya kurikulum dikembangkan berdasarkan keseimbangan antara kepentingan nasional dan kepentingan daerah. Kompetensi dan materi kurikulum dikembangkan berdasarkan keharmonisan antara kepentingan nasional untuk membangun kehidupan berbangsa yang kuat dan bermartabat dengan kepentingan daerah baik kepentingan sosial-budaya-ekonomi setempat maupun dalam kontribusinya terhadap pengembangan kehidupan daerah dalam rangka menuju ketercapaian tujuan pendidikan nasional.

KTSP seperti yang diamanatkan dalam PP Nomor 19 Tahun 2005 Tentang Standar Nasional Pendidikan adalah kurikulum operasional yang disusun oleh dan dilaksanakan di masing-masing satuan pendidikan (PP No.19/2005: 4). Pemahamannya adalah bahwa pada tingkat satuan pendidikan, yaitu sekolah, harus mengembangkan kurikulum sesuai dengan kebutuhan dan kondisinya masing-masing. Agar pengembangan kurikulum di tingkat satuan pendidikan dapat dilaksanakan sesuai kondisi nyata, maka sekolah harus memahami aturan tentang hal apa saja yang dapat ditetapkan di masing-masing sekolah dan hal apa saja yang telah ditetapkan secara nasional sebagai standar nasional. Sesuai dengan Peraturan Pemerintah tentang Standar Nasional Pendidikan penyusunan kurikulum pada satuan pendidikan jenjang pendidikan dasar dan menengah berpedoman pada panduan yang disusun oleh Badan Standar Nasional Pendidikan (BSNP). Untuk keperluan tersebut, sesuai tugas dan fungsinya sebagai pengembang kurikulum. Pusat Kurikulum membantu daerah untuk mengembangkan tim pengembang kurikulum agar mampu melakukan pendampingan kepada satuan pendidikan .

Hal lain yang perlu dicermati sehubungan dengan implikasi perubahan kurikulum setelah terbitnya Peraturan Pemerintah tentang Standar Nasional Pendidikan adalah menjawab pertanyaan mengapa harus ada kurikulum tingkat satuan pendidikan. Pentingnya kurikulum dikembangkan berdasarkan keseimbangan antara kepentingan nasional dan kepentingan daerah. Kompetensi dan materi kurikulum dikembangkan berdasarkan keharmonisan antara kepentingan nasional untuk membangun kehidupan berbangsa yang kuat dan bermartabat dengan kepentingan daerah baik kepentingan sosial-budaya-ekonomi setempat maupun dalam kontribusinya terhadap pengembangan kehidupan daerah dan sebaliknya kepentingan daerah tidak boleh diabaikan demi kepentingan lain.

KTSP dikembangkan berdasarkan prinsipprinsip: 1) berpusat pada potensi, perkembangan, kebutuhan, dan kepentingan peserta didik dan lingkungannya; 2) beragam dan terpadu; 3) tanggap terhadap perkembangan ilmu pengetahuan, teknologi dan seni; 4) relevan dengan kebutuhan kehidupan; 5) menyeluruh dan berkesinambungan; 6) belajar sepanjang hayat, dan 7) seimbang antara kepentingan nasional dan kepentingan daerah.

\section{Implementasi KTSP}

\section{Fungsi Perencanaan Pembelajaran dalam Penerapan KTSP}

Apapun dan bagaimanapun kurikulumnya, yang paling penting dilakukan adalah bagaimana guru dapat menjabarkan ke dalam Rencana Pelaksanaan Pembelajaran (RPP). Dengan kata lain, tugas utama guru dalam kaitannya dengan dokumen kurikum adalah membuat rencana pembelajaran yang akan dijadikan pedoman pelaksanaan pembelajaran dalam pencapaian kompetensi kompetensi peserta didik.

Menurut Mulyasa (2008a:148) kurikulum dan program pengajaran mencakup kegiatan perencanaan, pelaksanaan dan penilaian. 
Perencanaan dan pengembangan kurikulum telah dilakukan oleh Departemen Pendidikan Nasional pada tingkat pusat dalam bentuk standar isi. Oleh karena itu, pada tingkat sekolah yang paling penting adalah bagaimana merealisasian dan menyesuaikan kurikulum tersebut dengan kegiatan pembelajaran.

Demikian pentingnya perencanaan bagi guru, sehingga salah kalau ada anggapan bahwa guru cukup mengembangkan silabus. Silabus itu masih umum dan masih perlu dijabarkan ke dalam satuan perencanaan yang lebih khusus. Dalam hal ini silabus belum memuat secara rinci apa yang harus dilakukan oleh peserta didik, oleh guru dalam membantu peserta didik mencapai kompetensi, apa yang harus digunakan bagaimana caranya, serta berapa lama waktu yang diperlukan. Oleh karena itu, dalam setiap implementasi kurikulum, guru tetap dituntut dan harus membuat RPP.

Dalam implementasi KTSP, guru diberikan kewenangan secara leluasa untuk menganalisis Standar Kompetensi (SK) dan Kompetensi Dasar (KD) sesuai dengan karakteristik dan kondisi sekolah, serta kemampuan guru sendiri dalam menjabarkan menjadi silabus dan rencana pelaksanaan pembelajaran yang siap dijadikan pedoman pecapaian kompetensi peserta didik. Rencana pembelajaran yang baik adalah yang dapat dilaksanakan secara optimal dalam kegiatan pembelajaran dan pembentukan kompetensi peserta didik.

\section{Fungsi Pelaksanaan Pembelajaran dalam Penerapan KTSP}

Fungsi dan peranan penting guru dalam proses pembelajaran adalah sebagai fasilitator dalam belajar, artinya setiap guru diharapkan mampu mengarahkan kegiatan belajar peserta didik agar mencapai keberhasilan belajar sebagaimana ditetapkan dalam sasaran kegiatan proses belajar mengajar.

Suryosubroto, 1997 (dalam Mulyasa, 2008b) mengemukakan bahwa kemampuan guru dalam mengelola proses pembelajaran adalah kesanggupan atau kecakapan para guru dalam menciptakan suasana komunikatif yang edukatif antara guru dan peserta didik yang mencakup segi kognitif, afektif, psikomotorik sebagai upaya mempelajari sesuatu berdasarkan perencanaan sampai dengan tahap evaluasi dan tindak lanjut agar tercapai tujuan pembelajaran.

Kemampuan guru mengelola proses pembelajaran yang dimaksudkan adalah: 1) kemampuan dalam bidang kognitif artinya kemampuan intelektual, 2) kemampuan dalam afektif yaitu kesiapan dan kesediaan guru terhadap berbagai hal yang berkenaan dengan tugas dan profesinya, dan 3) kemampuan psikomotorik yaitu kemampuan guru dalam berbagai keterampilan dan perilaku. Selanjutnya, Mulyasa (2008a:180) implementasi KTSP akan bermuara pada pelaksanaan pembelajaran, yakni bagaimana agar isi atau pesan-pesan kurikulum dapat dicerna oleh peserta didik dapat membentuk kompetensi dirinya sesuai dengan apa yang digariskan dalam kurikulum, sebagaimana dijabarkan dalam rencana pelaksanaan pembelajaran.

Dalam hal ini akan terjadi interaksi antara peserta didik dengan lingkungan sehingga terjadi perubahan perilaku ke arah yang lebih baik. Tugas guru yang paling utama adalah mengkondisikan lingkungan agar menunjang terjadinya perubahan perilaku tersebut. Pada umumya pelaksanaan pembelajaran mencakup tiga kegiatan yakni pembukaan, pembentukan kompetensi dan penutup.

\section{Fungsi Evaluasi Pembelajaran dalam Penerapan KTSP}

Evaluasi adalah merupakan suatu proses berkelanjutan tentang pengumpulan dan penafsiran informasi untuk menilai keputusankeputusan yang dibuat dalam merancang suatu sistem pengajaran. Evaluasi adalah suatu proses memberikan pertimbangan mengenai nilai dan arti sesuatu yang dipertimbangkan. Menurut Cronbach dan Stufflebeam (dalam Arikunto, 2005) mendefenisikan evaluasi bahwa proses yang bukan sekedar mengukur sejauh mana tujuan tercapai, tetapi untuk membuat keputusan.

Dari beberapa konsep di atas, ada 2 hal yang menjadi karakteristik evaluasi sebagai berikut: 1) evaluasi merupakan proses artinya suatu pelaksanaan evaluasi mestinya terdiri dari berbagai tindakan yang harus dilakukan. Dengan demikian evaluasi bukanlah hasil atau produk, akan tetapi rangkaian kegiatan. Tindakan diberikan untuk memberikan makna atau nilai sesuatu 
yang dievaluasi, dan 2) evaluasi berhubungan dengan pemberian nilai atau arti, maksudnya berdasarkan hasil pertimbangan evaluasi dapat menunjukkan kualitas yang dinilai.

Dalam konteks kurikulum, evaluasi berfungsi: 1) untuk menilai keberhasilan peserta didik dalam pencapaian kompetensi, dan 2) sebagai umpan balik untuk perbaikan proses pembelajaran. Kedua fungsi tesebut adalah evaluasi sebagai fungsi sumatif dan evaluasi sebagai fungsi formatif.

\section{Kemampuan Guru IPA SMP}

Guru dalam UU Nomor 14 Tahun 2005 tentang Guru dan Dosen adalah pendidik profesional dengan tugas utama mendidik, mengajar, membimbing, mengarahkan, melatih, menilai, dan mengevaluasi peserta didik pada pendidikan anak usia dini jalur pendidikan formal, pendidikan dasar, dan pendidikan menengah. Oleh karena itu, secara profesional guru IPA SMP diharapkan mampu merencanakan dan melaksanakan serta melaporkan pelaksanaan pembelajaran sesuai dengan kurikulum tingkat satuan pendidikan

Mata pelajaran IImu Pengetahuan Alam (IPA) di SMP adalah merupakan keterpaduan bahan kajian Fisika, Biologi dan Kimia. Bahan kajian tersebut disusun dalam bentuk standar isi, yang terdiri dari standar kompetensi dan kompetensi dasar.

Standar Isi (SI) mencakup lingkup materi dan tingkat kompetensi untuk mencapai kompetensi lulusan pada jenjang dan jenis pendidikan tertentu. Termasuk dalam SI adalah: kerangka dasar dan struktur kurikulum, standar kompetensi dan kompetensi dasar setiap mata pelajaran pada setiap semester dari setiap jenis dan jenjang pendidikan dasar dan menengah. SI ditetapkan dengan Kepmendiknas Nomor 22 Tahun 2006 Standar Kompetensi Lulusan

Standar Kompetensi Lulusan (SKL) merupakan kualifikasi kemampuan lulusan yang mencakup sikap, pengetahuan dan keterampilan sebagaimana yang ditetapkan dengan Kepmendiknas Nomor 23 Tahun 2006. Standar Kompetensi dan Kompetensi Dasar merupakan arah dan landasan untuk mengembangkan materi pokok, kegiatan pembelajaran, dan indikator pencapaian kompetensi untuk penilaian. Sedang- kan dalam merancang kegiatan pembelajaran dan penilaian perlu memperhatikan standar proses dan standar penilaian.

Dalam kaitannya dengan KTSP, Depdiknas telah menyiapkan SK dan KD berbagai mata pelajaran, untuk dijadikan acuan oleh para pelaksana (guru) dalam mengembangkan KTSP pada satuan pendidikan masing-masing, termasuk SK dan KD IPA SMP.

Dengan demikian, tugas utama guru dalam KTSP adalah menjabarkan, menganalisis, mengembangkan indikator, dan menyesuaikan SK dan KD dengan karakteristik dan perkembangan peserta didik, situasi dan kondisi sekolah, serta kondisi dan kebutuhan daerah. Selanjutnya mengemas hasil analisis terhadap SK dan KD tersebut ke dalam KTSP, yang di dalamnya mencakup silabus dan RPP.

\section{Silabus KTSP}

Silabus adalah rencana pembelajaran pada suatu kelompok mata pelajaran dengan tema tertentu, yang mencakup SK, KD, materi pembelajaran, indikator, penilaian, alokasi waktu, dan sumber belajar yang dikembangkan oleh setiap satuan pendidikan. Dalam KTSP, silabus merupakan penjabaran SK dan KD ke dalam materi pembelajaran, kegiatan pembelajaran, dan indikator pencapaian kompetensi untuk penilaian hasil belajar.

Pada hakikatnya pengembangan silabus KTSP harus mampu menjawab pertanyaan sebagai berikut: 1) kompetensi apakah yang harus dimiliki oleh peserta didik?; 2) bagaimana cara mencapai kompetensi tersebut?; 3) bagaimana mengetahui bahwa peserta didik telah memiliki kompetensi itu? Dengan demikian, silabus dalam KTSP yang pengembangannya diserahkan kepada guru dimungkinkan akan berbeda antara satu guru dengan guru yang lain, baik dalam satu daerah ataupun dalam daerah yang berbeda. Namun demikian, dengan memperhatikan hakekat silabus di atas, suatu silabus minimal memuat lima komponen utama, yakni: 1) SK, 2) KD, 3) indikator, 4) materi standar, 5) standar proses, dan 6) standar penilaian. Pengembangan terhadap komponen-komponen tersebut merupakan kewenangan mutlak guru, termasuk pengembangan format dalam silabus, semakin membantu 
memudahkan guru dalam menjabarkannya ke alam RPP.

Dalam KTSP, pengembangan silabus diserahkan kepada guru dalam satuan pendidikan, khususnya bagi yang sudah mampu melakukannya. Oleh karena itu, setiap satuan pendidikan diberi kebebasan dan keleluasaan dalam mengembangkan silabus sesuai dengan kondisi dan kebutuhan masing-masing. Agar pengembangan silabus yang dilakukan oleh setiap satuan pendidikan tetap berada dalam bingkai pengembangan kurikulum nasional (standar nasional), maka perlu memperhatikan prinsip-prinsip pengembangan silabus. Prinsipprinsip tersebut adalah: ilmiah, relevan, fleksibel, kontinuitas, konsisten, memadai, aktual dan kontekstual, serta efektif, dan efisien.

Pengembangan silabus berbasis KTSP harus dilakukan dengan prinsip ilmiah, yang mengandung arti bahwa keseluruhan materi dan kegiatan yang menjadi muatan dalam silabus harus benar, logis, dan dapat dipertanggungjawabkan secara keilmuan.

Relevan dalam silabus mengandung arti bahwa ruang lingkup, kedalaman disesuaikan dengan karakteristik peserta didik: yakni: tingkat perkembangan intelektual, sosial, emosional, dan spiritual peserta didik. Di samping itu, relevan mengandung arti kesesuaian atau keserasian antara silabus dengan kebutuhan dan tuntutan kehidupan masyarakat pemakai lulusan. Dengan demikian, lulusan pendidikan harus sesuai dengan kebutuhan tenaga kerja di lapangan, baik secara kuantitas maupun kualitas. Relevan juga dikaitkan dengan jenjang pendidikan yang ada di atasnya, sehingga terjadi kesinambungan dalam pengembangan silabus.

Prinsip fleksibel mengandung makna pelaksana program, peserta didik, dan lulusan memiliki ruang gerak dan kebebasan dalam bertindak. Guru sebagai pelaksana silabus, tidak mutlak harus menyajikan program dengan konfigurasi seperti dalam silabus (dokumen tertulis), tetapi dapat mengakomodasi berbagai ide baru atau memperbaiki ide-ide sebelumnya. Demikian halnya peserta didik, mereka diberikan berbagai pengalaman belajar yang dapat dipilih sesuai dengan karakteristik dan kemampuan masing-masing. Sedangkan fleksibel dari segi lulusan dimaksudkan bahwa mereka memiliki kewenangan dan kemampuan yang multiarah berkaitan dengan dunia kerja yang akan dimasukinya.

Kontinuitas atau kesinambungan mengandung arti bahwa setiap program pembelajaran dikemas dalam silabus memiliki keterkaitan satu sama lain dalam membentuk kompetensi dan pribadi peserta didik. Kontinuitas bisa secara vertikal, yakni dengan jenjang pendidikan yang ada di atasnya; dan bisa juga secara horizontal yakni dengan program-program lain atau dengan silabus lain yang sejenis.

Pengembangan silabus berbasis KTSP harus dilakukan secara konsisten, artinya bahwa antara SK, KD, indikator, materi pokok, pengalaman belajar sumber belajar dan sistem penilaian memiliki hubungan yang konsisten dalam membentuk kompetensi peserta didik.

Memadai dalam silabus mengandung arti bahwa ruang lingkup indikator, materi standar, pengalaman belajar, sumber belajar dan sistem penilaian yang dilaksanakan dapat mencapai komptensi dasar yang telah ditetapkan. Di samping itu, prinsip memadai juga berkaitan dengan sarana dan prasarana, yang berarti bahwa KD yang dijabarkan dalam silabus, pencapaiannya ditunjang oleh sarana dan prasarana yang memadai.

Aktual dan kontekstual mengandung arti bahwa ruang lingkup KD, indikator, materi pokok, pengalaman belajar, sumber belajar, dan sistem penilaian yang dikembangkan memperhatikan perkembangan ilmu pengetahuan, teknologi, dan seni mutakhir dalam kehidupan nyata, dan peristiwa yang sedang terjadi dan berlangsung di masyarakat.

Pengembangan silabus harus dilakukan secara efektif, yakni memperhatikan keterlaksanaan silabus tersebut dalam proses pembelajaran, dan tingkat pembentukan kompetensi sesuai dengan SK yang telah ditetapkan. Efisien dalam silabus berkaitan dengan upaya untuk memperkecil atau menghemat penggunaan dana, daya, dan waktu tanpa mengurangi hasil atau kompetensi dasar yang ditetapkan. Efisien dalam silabus bisa dilihat dengan cara membandingkan antara biaya, tenaga, dan waktu yang digunakan untuk pembelajaran dengan hasil yang dicapai 
atau kompetensi yang dapat dicapai oleh peserta didik. Dengan demikian, setiap guru dituntut untuk dapat mengembangkan silabus dan perencanaan pembelajaran sehemat mungkin, tanpa mengurangi kualitas pencapaian dan pembentukan kompetensi.

Langkah penting yang harus dipahami guru dalam kaitannya dengan KTSP, ialah bahwa guru mampu mengkaji/menjabarkan kompetensi dasar dalam indikator kompetensi, yang siap dijadikan pedoman pembelajaran dan acuan penilaian Mengkaji dan menentukan KD mata pelajaran dengan memperhatikan: 1) urutan berdasarkan hierarki konsep disiplin ilmu dan tingkat kesulitan materi, tidak harus sesuai dengan urutan pada SI; 2) keterkaitan antar KD dalam mata pelajaran; dan 3) keterkaitan KD dengan SK.

Adapun langkah-langkah yang seyogyanya dapat dilakukan oleh guru dalam mengembangkan silabus adalah sebagai berikut: 1) mengisi identitas silabus yang terdiri dari nama sekolah, kelas, mata pelajaran, dan semester. Identitas silabus ditulis di atas matriks silabus; 2) menuliskan SK yang merupakan kemampuan peserta didik yang menggambarkan penguasaan pengetahuan, sikap, dan keterampilan yang diharapkan dicapai pada mata pelajaran tertentu. SK diambil dari SI (SK dan KD) Mata Pelajaran. Sebelum menuliskan SK, penyusun terlebih dahulu mengkaji Standar Isi mata pelajaran dengan memperhatikan: urutan berdasarkan hierarki konsep disiplin ilmu dan/atau SK dan KD, keterkaitan antar SK dan KD dalam mata pelajaran dan keterkaitan SK dan KD antarmata pelajaran; 3) menuliskan KD merupakan sejumlah kemampuan minimal yang harus dimiliki peserta didik dalam rangka menguasai SK mata pelajaran tertentu. KD dipilih dari yang tercantum dalam SI. Sebelum menentukan atau memilih KD, penyusun terlebih dahulu mengkaji SK dan KD mata pelajaran dengan memperhatikan: urutan berdasarkan hierarki konsep disiplin ilmu dan/ atau tingkat kesulitan KD, keterkaitan antar SK dan KD dalam mata pelajaran, dan keterkaitan SK dan KD antarmata pelajaran; 4) mengidentifikasi materi pokok/pembelajaran, 5) mengembangkan kegiatan pembelajaran, 6) Merumuskan indikator pencapaian kompetensi dasar yang ditandai oleh perubahan perilaku yang dapat diukur yang mencakup sikap, pengetahuan, dan keterampilan. Indikator dikembangkan sesuai dengan karakteristik peserta didik, mata pelajaran, satuan pendidikan, potensi daerah dan dirumuskan dalam kata kerja operasional yang terukur dan/atau dapat diobservasi. Indikator digunakan sebagai dasar untuk menyusun alat penilaian, 7) menetapkan sistem penilaian untuk mengukur pencapaian KD peserta didik dilakukan berdasarkan indikator. Di dalam kegiatan penilaian ini terdapat tiga komponen penting, yang meliputi: teknik penilaian, bentuk instrumen, dan contoh instrumen; 8) menentukan alokasi waktu yang merupakan jumlah waktu yang dibutuhkan untuk ketercapaian suatu KD tertentu, dengan memperhatikan: minggu efektif persemester; alokasi waktu mata pelajaran, dan jumlah kompetensi persemester; dan 9) menentukan sumber belajar yang diperlukan dalam kegiatan pembelajaran, yang dapat berupa: buku teks, media cetak, media elektronika, nara sumber, lingkungan alam sekitar, dan sebagainya.

\section{Rencana Pelaksanaan Pembelajaran (RPP) dalam KTSP}

RPP adalah rencana yang menggambarkan prosedur dan pengorganisasian pembelajaran untuk mencapai satu KD yang ditetapkan dalam Standar Isi dan dijabarkan dalam silabus. Lingkup Rencana Pembelajaran paling luas mencakup 1 (satu) KD yang terdiri minimal 3 (tiga) indikator untuk 1 (satu) kali pertemuan atau lebih. Sedikitnya terdapat 2 fungsi RPP dalam KTSP. Kedua fungsi tersebut adalah fungsi perencanan dan fungsi pelaksanaan. Fungsi perencanaan RPP dalam KTSP adalah bahwa RPP hendaknya dapat mendorong guru lebh siap melakukan kegiatan pembelajaran dengan perencanaan yang matang. Oleh karena itu, setiap akan melakukan pembelajaran guru wajib memiliki persiapan, baik persiapan tertulis maupun tidak tertulis. Komponen-komponen yang harus dipahami guru dalam pengembangan KTSP antara lain: KD, materi standar, hasil belajar, indikator hasil belajar, penilaian, dan prosedur pembelajaran.

Dalam pengembangan KTSP, RPP disusun secara sistemik dan sistematis, utuh dan menyuluruh, dengan beberapa kemungkinan penyesuian dalam situasi pembelajaran yan 
aktual. Dengan demikian, RPP berfungsi untuk mengefektikan proses pembelajaran sesuai dengan apa yang direncanakan. Dalam hal ini, materi standar yang dikembangkan dan dijadikan bahan kajian oleh peserta didik harus disesuaikan dengan kebutuhan dan kemampuan, mengandung nilai fungsional, praktis, serta disesuaikan dengan kondisik dan kebutuhan lingkungan, sekolah, dan daerah. Oleh karena itu, kegiatan pembelajaran harus terorganisasi melalui serangkaian kegiatan tertentu, dengan strategi yang tepat.

RPP minimal berisi: tujuan pembelajaran, materi ajar, metode pembelajaran, sumber belajar, dan penilaian hasil belajar. Tujuan pembelajaran adalah perilaku hasil belajar yang diharapkan terjadi, dimiliki, atau dikuasai oleh siswa setelah mengikuti kegiatan pembelajaran tertentu. Pengertian lain menyebutkan, bahwa tujuan pembelajaran adalah pernyataan mengenai aspek kognitif, afektif, dan psikomotor yang diharapkan dapat dikuasai oleh siswa pada setiap proses pembelajaran.

Perumusan tujuan pembelajaran merupakan tahapan penting dalam rangkaian penyusunan RPP. Hal ini cukup beralasan karena: 1) dengan adanya tujuan pembelajaran, siswa dapat mengatur waktu, energi, dan pemusatan perhatian pada tujuan pembelajaran yang akan dicapai; 2) dengan adanya tujuan pembelajaran, guru dapat mengatur kegiatan (pengelolaan kelas, penggunaan sumber/media pembelajaran, dan menggunaan model pembelajaran) untuk mencapai tujuan pembelajaran; dan 3) dengan adanya tujuan pembelajaran, evaluator dapat menyusun alat evaluasi dengan tujuan pembelajaran.

Dalam konteks KTSP, tujuan pembelajaran yang diharapkan dapat dicapai oleh siswa dalam setiap pembelajaran tetap berorientasi kepada taksonomi tujuan pembelajaran yang terdiri atas tujuan kognitif, tujuan afektif, dan tujuan psikomotor yang bermuara kepada pencapaian kecakapan hidup siswa (kecakapan intelektual, kecakapan sosial, dan kecakapan spritual). Materi pembelajaran adalah materi yang digunakan untuk mencapai tujuan pembelajaran. Materi pembelajaran dikembangkan dengan mengacu pada materi pokok yang ada dalam silabus.
Metode dapat diartikan benar-benar sebagai metode, tetapi dapat pula diartikan sebagai model atau pendekatan pembelajaran, bergantung pada karakteristik pendekatan dan/atau strategi yang dipilih.

Untuk mencapai suatu kompetensi dasar harus dicantumkan langkah-langkah kegiatan setiap pertemuan. Pada dasarnya, langkahlangkah kegiatan memuat unsur kegiatan pendahuluan/pembuka, kegiatan inti, dan kegiatan penutup. Akan tetapi, dimungkinkan dalam seluruh rangkaian kegiatan, sesuai dengan karakteristik model yang dipilih, menggunakan urutan sintaks sesuai dengan modelnya. Oleh karena itu, kegiatan pendahuluan/pembuka, kegiatan inti, dan kegiatan penutup tidak harus ada dalam setiap pertemuan.

Pemilihan sumber dan media pembelajaran mengacu pada perumusan yang ada dalam silabus yang dikembangkan oleh satuan pendidikan. Sumber belajar mencakup sumber rujukan, lingkungan, media, narasumber, alat, dan bahan. Sumber belajar dituliskan secara lebih operasional. Misalnya, sumber belajar dalam silabus dituliskan buku referens, dalam RPP harus dicantumkan judul buku teks tersebut, pengarang, dan halaman yang diacu.

Penilaian dijabarkan atas teknik penilaian, bentuk instrumen, dan instrumen yang dipakai untuk mengumpulkan data. Dalam sajiannya dapat ituangkan dalam bentuk matrik horisontal atau vertikal. Apabila penilaian menggunakan teknik tes tertulis uraian, tes unjuk kerja, dan tugas rumah yang berupa proyek harus disertai rubrik penilaian.

\section{Remedial dan Pengayaan}

Berdasarkan teori belajar tuntas, maka seorang peserta didik dipandang tuntas belajar jika ia mampu menyelesaikan, menguasai kompetensi atau mencapai tujuan pembelajaran minimal $65 \%$ dari seluruh tujuan pembelajaran. Sedangkan keberhasilan kelas dilihat dari jumlah peserta didik yang mampu menyelesaikan atau mencapai minimal $65 \%$, sekurang-kurangnya $85 \%$ dari jumlah peserta didik yang ada di kelas tersebut.

Sekolah perlu memberikan perlakuan khusus terhadap peserta didik yang mendapat kesulitan belajar melalui kegiatan remedial. Peserta didik cemerlang diberikan kesempatan untuk tetap 
mempertahankan kecepatan belajarnya melalui kegiatan pengayaan. Kedua program itu diberlakukan oleh sekolah karena lebih mengetahui dan memahami kemajuan belajar setiap peserta didik (Mulyasa, 2008b:151).

Dalam rangka membantu peserta didik mencapai standar isi dan standar kompetensi lulusan, pelaksanaan atau proses pembelajaran perlu diusahakan agar interaktif, inspiratif, menyenangkan, menantang, memotivasi peserta didik untuk berpartisipasi aktif, serta memberikan kesempatan yang cukup bagi prakarsa, kreativitas, dan kemandirian sesuai dengan bakat, minat, dan perkembangan fisik serta psikologis peserta didik. Kendati demikian, tidak dapat dipungkiri bahwa untuk mencapai tujuan dan prinsip-prinsip pembelajaran tersebut pasti dijumpai adanya peserta didik yang mengalami kesulitan atau masalah belajar. Untuk mengatasi masalah-masalah tersebut, setiap satuan pendidikan perlu menyelenggarakan program pembelajaran remedial atau perbaikan.

Pembelajaran remedial merupakan layanan pendidikan yang diberikan kepada peserta didik untuk memperbaiki prestasi belajarnya sehingga mencapai kriteria ketuntasan yang ditetapkan. Untuk memahami konsep penyelenggaraan model pembelajaran remedial, terlebih dahulu perlu diperhatikan bahwa KTSP yang diberlakukan berdasarkan Permendiknas 22, 23, 24 Tahun 2006 dan Permendiknas No. 6 Tahun 2007 menerapkan sistem pembelajaran berbasis kompetensi, sistem belajar tuntas, dan sistem pembelajaran yang memperhatikan perbedaan individual peserta didik. Sistem dimaksud ditandai dengan dirumuskannya secara jelas SK dan KD yang harus dikuasai peserta didik. Penguasaan SK dan KD setiap peserta didik diukur menggunakan sistem penilaian acuan kriteria. Jika seorang peserta didik mencapai standar tertentu maka peserta didik dinyatakan telah mencapai ketuntasan.

Dengan diberikannya pembelajaran remedial bagi peserta didik yang belum mencapai tingkat ketuntasan belajar, maka peserta didik ini memerlukan waktu lebih lama daripada mereka yang telah mencapai tingkat penguasaan. Mereka juga perlu menempuh penilaian kembali setelah mendapatkan program pembelajaran remedial.

\section{Kerangka Berpikir}

Dalam penelitian ini dibuat kerangka berpikir penelitian yang digunakan sebagai acuan dalam pelaksanaan penelitian. Alur dalam penelitian ini dapat dilihat pada Gambar 1.

\section{Metode Penelitian}

Penelitian ini merupakan penelitian deskriptif jenis survei yang bertujuan untuk mendeskripsikan pendapat guru dalam mengimplementasikan

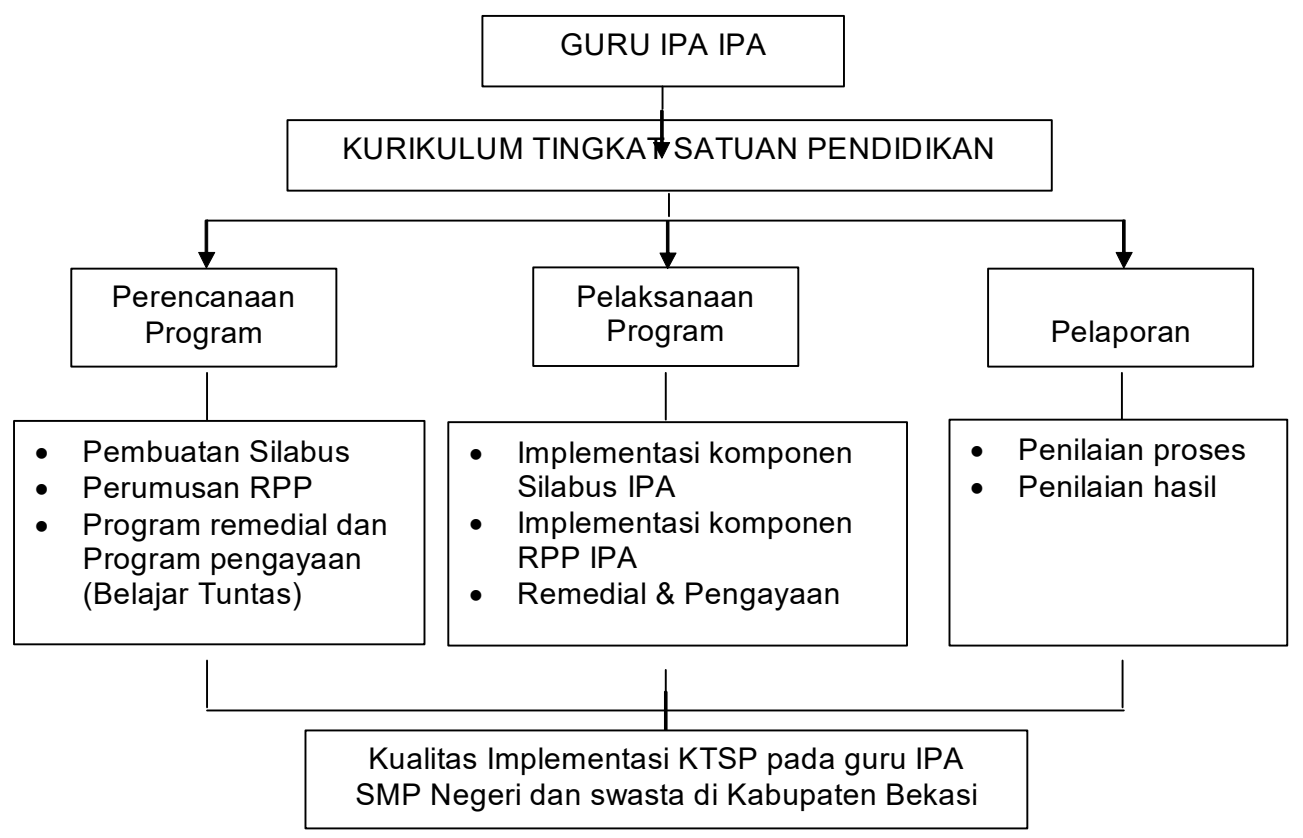

Gambar 1. Kerangka Pikir 
perencanaan program, pelaksanaan program, dan pelaporan program pembelajaran IPA dalam pelaksanaan KTSP dengan melibatkan sebanyak 40 guru IPA yang tersebar di 11 SMP Negeri dan Swasta di Kabupaten Bekasi sebagai sampel penelitian.

Data tentang Implementasi Kurikulum Tingkat Satuan Pendidikan dalam pembelajaran IPA SMP dijaring dengan menggunakan instrumen kuesoner sebanyak 65 pernyataan/pertanyaan yang terdiri atas: 1) dimensi perencanaan program sebanyak 25 pernyataan/pertanyaan yang meliputi tentang pembuatan silabus, perumusan RPP, program remedial dan pengayaan, 2) dimensi pelaksanaan program sebanyak 23 pernyataan/ pertanyaan yang meliputi tentang implementasi komponen silabus IPA, implementasi komponen RPP IPA, dan remedial-pengayaan, dan 3) dimensi pelaporan program sebanyak 17 pernyataan/ pertanyaan yang meliputi tentang penilaian proses dan hasil.

Data yang diperoleh dianalisis dengan cara menghitung persentase untuk setiap indikator dan untuk setiap dimensi dalam implementasi KTSP. Analisis ini bertujuan untuk mengetahui totalitas penerapan KTSP oleh guru pada setiap indikator dan setiap dimensi yang telah ditentukan dengan langkah-langkah sebagai berikut: 1) mengetahui jumlah responden yang mengisi kuesioner, 2) menghitung jumlah item pada setiap indikator dan pada setiap dimensi masalah, 3) menjumlahkan pilihan yang sama dari item-item pada setiap indikator dan pada setiap dimensi, dan 4) menghitug persentase setiap indikator dan dimensi dengan hasil kali antara jumlah item pada satu indikator atau satu dimensi dengan jumlah responden

Parameter yang digunakan untuk interpretasi kategori adalah mengacu kepada skala instrumen, karena instrumen meggunakan option/pilihan dalam bentuk gradasi yang terdiri dari 5 klasifikasi kategori yaitu: mulai dari klasifikasi tidak pernah dikategorikan sangat rendah sampai ke tingkat yag lebih tinggi yaitu klasifikasi selalui dikategorikan sangat tinggi.

\section{Hasil dan Pembahasan}

Hasil penelitian yang diperoleh melalui kuesioner telah dianalisis dengan persentase setiap indikator dan persentase setiap dimensi pada butir penyajian hasil analisis data.

\section{Perencanaan program}

Analisis persentase tentang indikator pembuatan silabus memperlihatkan bahwa $45.5 \%$ memilih selalu/sangat setuju, $37.2 \%$ responden memilih sering/setuju, dan sisanya memilih tidak pernah/ tidak setuju. Kenyataan ini menunjukkan bahwa guru IPA mempunyai pilihan yang bervariasi dalam melaksanakan indikator ini. Analisis persentase tentang indikator perumusan RPP IPA memperlihatkan bahwa $61.1 \%$ memilih selalu/sangat setuju, $34.3 \%$ responden memilih sering/setuju, dan sisanya memilih kadang-kadang/ragu-ragu. Berdasarkan kenyataan tersebut menunjukkan bahwa guru IPA memilih selalu/sangat setuju dalam melaksanakan indikator ini. Analisis persentase tentang indikator program remedial dan pengayaan memperlihatkan bahwa $26.9 \%$ memilih selalu/sangat setuju, $52.7 \%$ responden memilih sering/setuju, dan sisanya memilih jarang/tidak setuju. Berdasarkan kenyataan tersebut menunjukkan bahwa guru IPA mempunyai pilihan yang bervariasi.

\section{Pelaksanaan program}

Analisis persentase tentang indikator implementasi komponen silabus memperlihatkan bahwa memperlihatkan bahwa 44.4\% memilih selalu/sangat setuju, $37.9 \%$ responden memilih sering/setuju, dan sisanya jarang/tidak setuju. Berdasarkan kenyataan tersebut menunjukkan bahwa guru IPA mempunyai pilihan yang selalu/ sangat setuju dalam melaksanakan indikator ini. Analisis persentase tentang indikator implementasi komponen RPP fisika memperlihatkan bahwa memperlihatkan bahwa 59.6\% memilih selalu/sangat setuju, $37.9 \%$ responden memilih sering/setuju, dan sisanya memilih jarang/tidak setuju. Berdasarkan kenyataan tersebut menunjukkan bahwa guru IPA mempunyai pilihan yang selalu/sangat setuju dalam melaksanakan indikator ini.

Analisis persentase tentang indikator remedial dan pengayaan memperlihatkan bahwa memperlihatkan bahwa $28.2 \%$ memilih selalu/ sangat setuju, $60.0 \%$ responden memilih sering/ setuju, dan sisanya meilih jarang/tidak setuju. 


\section{Pelaporan program}

Analisis persentase tentang indikator remedial dan pengayaan memperlihatkan bahwa memperlihatkan bahwa $63.1 \%$ memilih selalu/sangat setuju, $24.4 \%$ responden memilih sering/setuju, dan sisanya memilih kadang-kadang/ragu-ragu. Berdasarkan kenyataan tersebut menunjukkan bahwa guru IPA mempunyai pilihan selalu/sangat setuju dalam melaksanakan indikator ini.

\section{Pembahasan Hasil Analisis Data Setiap Dimensi}

Pembahasan hasil penelitian dipandang dari analisis tiap dimensi yang terdiri dari perencanaan program, pelaksanaan program, dan pelaporan didapatkan sebagai berikut:

Pengukuran perencanaan program, dilakukan dengan menggunakan instrumen kuesioner yang memuat 25 butir pernyataan dengan 5 alternatif pilihan jawaban dan responden wajib memilih salah satu diantaranya sebagai jawaban. Dengan demikian skor teoretisnya adalah 25 sebagai skor terendah dan 125 sebagai skor tertingggi yang mungkin diperoleh responden. Berdasarkan skor teoretis tersebut, maka untuk mengetahui distribusi frekuensi masing-masing kategori dapat dilihat pada Tabel 1 berikut.

Tabel 1. Distribusi frekuensi perencanaan program

\begin{tabular}{|l|c|c|c|}
\hline Kategori & Skor & $\begin{array}{c}\text { Persentase } \\
(\%)\end{array}$ & Frekuensi \\
\hline SL/SS & $23-42$ & 47.2 & 393 \\
\hline SR/S & $44-46$ & 39.3 & 473 \\
\hline KK/R & $65-85$ & 30.5 & 105 \\
\hline JR/TS & $86-106$ & 2.2 & 22 \\
\hline TP/STS & $107-127$ & 0.7 & 7 \\
\hline Jumlah & & 100 & 1.000 \\
\hline
\end{tabular}

Berdasarkan distribusi frekuensi pada tabel 1 di atas, memberi gambaran bahwa persentase dimensi perencanaan program memperlihatkan bahwa $47.3 \%$ memilih selalu/sangat setuju, dan hanya $0.7 \%$ responden memilih tidak pernah/ sangat tidak setuju. Berdasarkan kenyataan tersebut menunjukkan bahwa guru IPA mempunyai pilihan selalu/sangat setuju dalam melaksanakan dimensi pengembangan program. Sehingga dapat disimpulkan untuk dimensi ini, guru IPA SMP Negeri dan Swasta di kabupaten Bekasi termasuk kategori cukup tinggi. Untuk lebih jelasnya, dapat dilihat histogram pada gambar berikut ini.

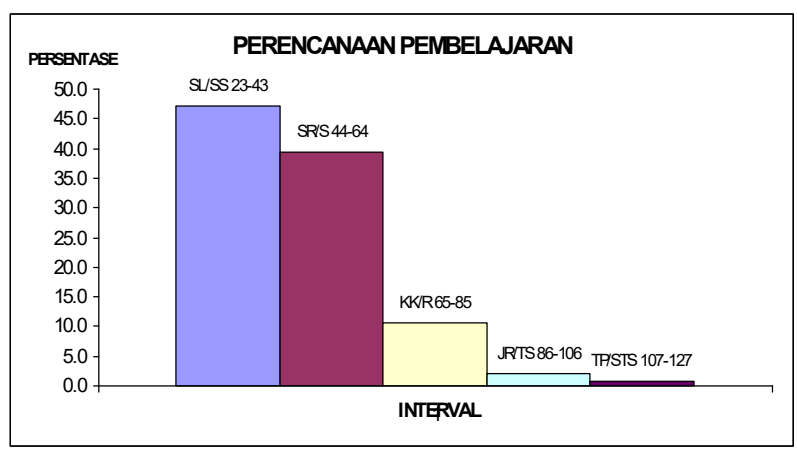

Gambar. 2. Histogram perencanaan pembelajaran

Pengukuran pelaksanaan program, dilakukan dengan menggunakan instrumen kuesioner yang memuat 23 butir pernyataan dengan 5 alternatif pilihan jawaban dan responden wajib memilih salah satu diantaranya sebagai jawaban. Dengan demikian skor teoretisnya adalah 23 sebagai skor terendah dan 115 sebagai skor tertingggi yang mungkin diperoleh responden. Berdasarkan skor teoretis tersebut, maka untuk mengetahui distribusi frekuensi masing-masing kategori dapat dilihat pada Tabel 2 berikut.

Tabel. 2. Distribusi frekuensi pelaksanaan program

\begin{tabular}{|l|c|c|c|}
\hline Kategori & Skor & $\begin{array}{c}\text { Persentase } \\
(\%)\end{array}$ & Frekuensi \\
\hline SL/SS & $23-41$ & 46.8 & 431 \\
\hline SR/S & $42-60$ & 42.7 & 393 \\
\hline KK/R & $61-79$ & 7.3 & 105 \\
\hline JR/TS & $80-98$ & 2.6 & 67 \\
\hline TP/STS & $99-117$ & 0.6 & 5 \\
\hline Jumlah & & 100 & 920 \\
\hline
\end{tabular}


Berdasarkan distribusi frekuensi pada Tabel 2. di atas, persentase tentang dimensi pelaksanaan program memperlihatkan bahwa $46.8 \%$ responden memilih selalu/sangat setuju, dan hanya $0.6 \%$ responden memilih tidak pernah/ sangat tidak setuju. Berdasarkan kenyataan tersebut menunjukkan bahwa guru IPA mempunyai pilihan selalu/sangat setuju dalam melaksanakan dimensi pelaksanaan program. Sehingga dapat disimpulkan untuk dimensi ini, guru IPA SMP Negeri dan Swasta di kabupaten Bekasi termasuk kategori cukup tinggi. Untuk lebih jelasnya, dapat dilihat histogram pada gambar berikut ini.

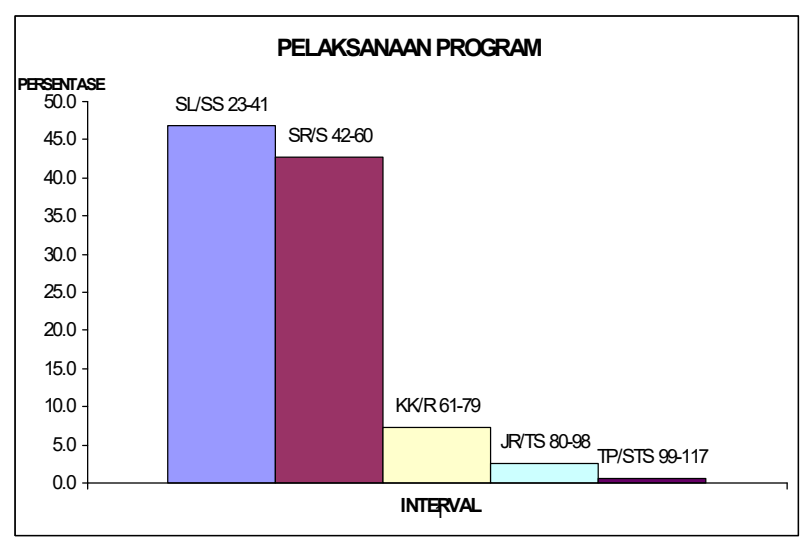

Gambar 3. Histogram pelaksanaan pembelajaran

Pengukuran pelaporan program, dilakukan dengan menggunakan instrumen kuesioner yang memuat 17 butir pernyataan dengan 5 alternatif pilihan jawaban dan responden wajib memilih salah satu diantaranya sebagai jawaban. Dengan demikian skor teoretisnya adalah 17 sebagai skor terendah dan 85 sebagai skor tertingggi yang mnungkin diperoleh responden. Berdasarkan skor teoretis tersebut, maka untuk mengetahui distribusi frekuensi masing-masing kategori dapat dilihat pada Tabel 3.

Berdasarkan distribusi frekuensi pada Tabel 3 di atas persentase tentang dimensi pelaporan memperlihatkan bahwa $42.5 \%$ memilih selalu/ sangat setuju, $42.8 \%$ responden memilih sering/ setuju, dan $0.3 \%$ responden memilih tidak pernah/ sangat tidak setuju. Berdasarkan kenyataan tersebut menunjukkan bahwa guru IPA mempunyai pilihan selalu/sangat setuju dan
Tabel 3. Distribusi frekuensi pelaporan program

\begin{tabular}{|l|c|c|c|}
\hline \multicolumn{1}{|c|}{ Kategori } & Skor & $\begin{array}{c}\text { Persentase } \\
(\%)\end{array}$ & Frekuensi \\
\hline SL/SS & $14-28$ & 42.5 & 289 \\
\hline SR/S & $29-43$ & 42.8 & 291 \\
\hline KK/R & $44-58$ & 12.3 & 84 \\
\hline JR/TS & $59-73$ & 2.1 & 14 \\
\hline TP/STS & $74-88$ & 0.3 & 2 \\
\hline Jumlah & & 100 & 680 \\
\hline
\end{tabular}

sering/setuju dalam melaksanakan dimensi pelaporan mempunyai persentase yang sama. Sehingga dapat disimpulkan untuk dimensi ini, guru IPA SMP Negeri dan Swasta di Kabupaten Bekasi termasuk kategori cukup tinggi. Untuk lebih jelasnya, dapat dilihat histogram pada Gambar 4 berikut ini.

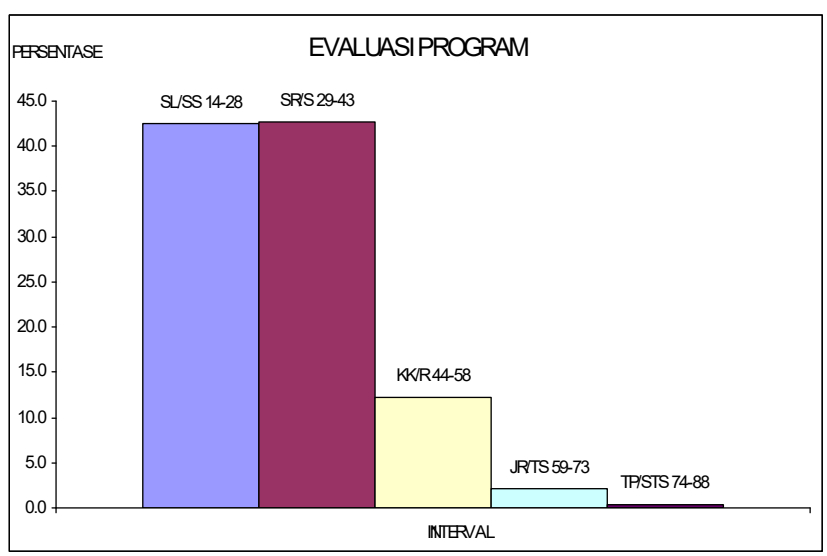

Gambar 4. Histogram pelaporan pembelajaran

\section{Simpulan dan Saran}

\section{Simpulan}

Beberapa kesimpulan yang dapat diambil dari hasil penelitian ini adalah sebagai berikut:

Pertama, perencanaan program dalam implementasi kurikulum tingkat satuan pendidikan pada SMP Negeri dan Swasta di Kabupaten Bekasi pada pembelajaran IPA yang meliputi pembuatan silabus, perumusan RPP IPA dan program remedial-pengayaan, termasuk dalam kategori cukup. Kedua, pendapat guru tentang pelaksanaan program dalam implementasi kurikulum tingkat satuan pendidikan pada SMP Negeri dan Swasta di Kabupathen Bekasi pada pembelajaran IPA yang meliputi implementasi komponen silabus, implementasi komponen RPP IPA dan program 
remedial-pengayaan, termasuk dalam kategori cukup. Ketiga, pelaporan hasil pelaksanaan dalam implementasi kurikulum tingkat satuan pendidikan pada SMP Negeri dan swasta di Kabupaten Bekasi pada pembelajaran IPA yang meliputi penilaian roses dan penilaian hasil termasuk dalam kategori tinggi. Keempat, dari ketiga dimensi perencanaan program, pelaksanaan program, dan pelaporan program, ternyata pendapat guru-guru IPA SMP Negeri dan Swasta di Kabupaten Bekasi, menunjukkan bahwa dimensi pelaksanaan program yang lebih dominan dilaksanakan.

\section{Saran}

Berdasarkan simpulan penelitian maka berikut ini diajukan beberapa saran. Kepada guru mata pelajaran IPA pada SMP Negeri dan Swasta di Kabupaten Bekasi agar: Pertama, lebih baik dalam melaksanakan setiap komponen kurikulum KTSP, mulai dari perencanaan program, pelaksanaan program, dan pelaporan hasil belajar. Kedua, lebih memperhatikan kesesuaian dengan peserta didik dan lingkungan dalam pembuatan silabus IPA, RPP IPA, dan program pengayaan-remedial. Ketiga, lebih kreatif dan inovatif dalam menciptakan suasana pembelajaran, pemilihan buku, strategi pembelajaran, karena dalam KTSP ini sekolah memiliki kewenangan dalam menetapkan kurikulum dan cara pembelajaran sesuai visi, misi dan tujuannya. Keempat, untuk Dinas Pendidikan Kabupaten Bekasi, walaupun pencapaian implementasi KTSP di SMP Negeri dan Swasta Kabupaten Bekasi menurut guru-guru sebagai responden, sudah berada pada tataran cukup tinggi, namun akan lebih baik lagi bila lebih sering mengadakan pelatihan pemantapan KTSP ini kepada guru-guru IPA khususnya dan guru mata pelajaran lain pada umumnya.

\section{Pustaka Acuan}

Arikunto, S. 2005. Dasar-dasar Evaluasi Pendidikan. Jakarta: Bumi Aksara.

Mulyasa. 2008a. Kurikulum Tingkat Satuan Pendidikan. Bandung: Remaja Rosdakarya.

Mulyasa. 2008b. Menjadi Guru Profesional. Bandung: Remaja Rosdakarya.

Panduan Penyusunan Kurikulum Tingkat Satuan Pendidikan, Jenjang Pendidikan Dasar dan Menengah, BSNP, Jakarta, 2006.

Peraturan Pemerintah Nomor 19 Tahun 2005 tentang Standar Nasional Pendidikan, BSNP, Jakarta, 2006.

Peraturan Menteri Pendidikan Nasional No. 22 Tahun 2006 Standar Isi

Peraturan Menteri Pendidikan Nasional No. 23 Tahun 2006 Tentang Standar Kompetensi Lulusan

Peraturan Menteri Pendidikan Nasional Nomor: 24 Tahun 2006 Tentang Pelaksanaan Standar Isi dan Standar Kompetensi Lulusan

Undang-Undang Republik Indonesia Nomor 20 Tahun 2003 tentang Sistem Pendidikan Nasional, Depdiknas Republik Indonesia, Jakarta, 2006.

Undang-Undang Republik Indonesia Nomor 14 Tahun 2005 tentang Guru dan Dosen, Jakarta, 2005 